PHAM-THUOC, Jerzy SZYPU£A

Fish Biology

\title{
BIOLOGICAL CHARACTERISTIC OF GILT SARDINE \\ SARDINELLA AURITA CUV. et VAL., 1847 \\ FROM NORTH WEST AFRICAN COAST \\ CHARAKTERYSTYKA BIOLOGICZNA SARDYNELI \\ SARDINELLA AURITA CUV. let VAL., 1847 \\ Z LOWISK PÓŁNOCNO-ZACHODNIEJ AFRYKI
}

\author{
Institut of Ichthyology \\ Department of Biology of Fishes
}

Presented in this work is the biological characteristic of gilt sardine. The investigation comprised: length, age, rate of growth in length and weight, maturity of gonads and fecundity, food and intensity of feeding.

\section{INTRODUCTION}

Gilt sardine - Sardinella aurita Cuv. et Val., 1847 - is one of the basic species of Sardinella genus subjected to fishing. Beyond it, also important from industrial point of view, are the species belonging to Sardinella eba (Cuv. et Val.) and Sardinella aurita terrasae (Lozano).

Gilt sardine plays relatively important part in the world fishing and its catches particularly increasing in West-African waters. The results of investigation performed on this species indicate that large reserves of it still exist in many regions, which so far have been no substantially exploited or used by fishery.

According to data of FAO for 1958-1968, the highest catches of gilt sardine were noted for 1964 (170 500 tons) against 59400 tons only for 1958. 
This work was aimed for investigation of basic biological features of gilt sardine. Subjected to investigation were the age, rate of growth, reproduction and fecundity, food and feeding of this species.

\section{MATERIAL AND METHOD}

The materials used for this work comprised 13434 pcs of gilt sardine collected during 1968-1970. They originated from industrial fishing carried out by Polish fishing ships belonging to „Odra” Swinoujście and „Gryf” Szczecin. The materials of April 1968 were offered by dr A. Klimaj from MIR (Institute of Sea Fisheries). The quantity of particular samples and the time and place of catches are given in tab. 1 .

Table 1

Summary of collected material

\begin{tabular}{ccr}
\hline Date & Region of fishing & Number of specimen \\
\hline 2 IV 1968 & $15^{\circ} 57^{\prime} \mathrm{N}-16^{\circ} 53^{\prime} \mathrm{W}$ & 100 \\
15 IX 1968 & $21^{\circ} 41^{\prime} \mathrm{N}-17^{\circ} 28^{\prime} \mathrm{W}$ & 92 \\
8 XII 1968 & - & 245 \\
24 I 1969 & $17^{\circ} 43^{\prime} \mathrm{N}-16^{\circ} 21^{\prime} \mathrm{W}$ & 153 \\
1 II 1969 & $20^{\circ} 22^{\prime} \mathrm{N}-17^{\circ} 37^{\prime} \mathrm{W}$ & 212 \\
28 II 1969 & $14^{\circ} 17^{\prime} \mathrm{N}-17^{\circ} 25^{\prime} \mathrm{W}$ & 76 \\
18 III 1969 & $21^{\circ} 10^{\prime} \mathrm{N}-17^{\circ} 25^{\prime} \mathrm{W}$ & 76 \\
5 IV 1969 & $20^{\circ} 40^{\prime} \mathrm{N}-17^{\circ} 20^{\prime} \mathrm{W}$ & 190 \\
16 V 1969 & $24^{\circ} 40^{\prime} \mathrm{N}-15^{\circ} 30^{\prime} \mathrm{W}$ & 170 \\
9 VI 1969 & $16^{\circ} 25^{\prime} \mathrm{N}-16^{\circ} 43^{\prime} \mathrm{W}$ & 821 \\
$21-22$ VII 1969 & $23^{\circ} 00^{\prime} \mathrm{N}-17^{\circ} 00^{\prime} \mathrm{W}$ & 285 \\
21,27 VIII 1969 & - & 177 \\
18 IX 1969 & $21^{\circ} 32^{\prime} \mathrm{N}-17^{\circ} 30^{\prime} \mathrm{W}$ & 160 \\
20 XI 1969 & - & 332 \\
24,27 V 1970 & $16^{\circ} 38^{\prime} \mathrm{N}-16^{\circ} 43^{\prime} \mathrm{W}$ & 7992 \\
11 VI 1970 & $17^{\circ} 03^{\prime} \mathrm{N}-16^{\circ} 40^{\prime} \mathrm{W}$ & 2353 \\
\hline
\end{tabular}

Total

13434

The length of fish was measured with an accuracy up to $0,5 \mathrm{~cm}$. Two lengths were determined, viz.: longitudo totalis - used thenafter for all length and growth summaries, and longitudo caudalis - used thenafter for comparison of the present results with those of other authors who used the same length.

The weight of gilt sardine was determined with an accuracy up to $5 \mathrm{~g}$; weighed was the fish as whole and the fish without entrails. 
The scales used for determination of age and rate of growth, were taken from the locality situated between the caudal and dorsal fins along the golden lateral strip. It must be underlined that the scales of gilt sardine are not very illegible and clear and numberous additional false annulus are present. This necessitated the analysis of several scales from each specimen to minimize the probability of error. In determination of age and rate of growth the otoliths and opercular bones, were used additionally as their legibility is lower than of scales, while the scales were used as basic material.

The fecundity of gilt sardine was determined by weighing method based on the female gonads of IV. and V. maturity stage according to Maier's scale. For determination of alimentary tracts filling assumed the 5-grade scale ( 0 to 4$)$ and the index of filling was calculated as relationship of foodweight to the weight of a fish.

The composition of food was determined by the analysis of content in alimentary tracts. The participation of particular food components is presented according to the frequency of its occurence.

\section{HYDROLOGIC FEATURES OF INVESTIGATED REGION}

The region, where the examined fishes were caught, comprises North-African shelf between the estuary of Rio de Oro river in the north, down to Cap Verde in the south, what according to Klimaj (1968) is the part of Second Fishing Region. This region remains under constant influence of the trade wind, particularly in spring - summer season. The cold currents of Canary Islands occuring in this region are also assigned to an activity of these winds. The temperature of surfacial waters oscillates between $17^{\circ} \mathrm{C}-21^{\circ} \mathrm{C}$ and its salinity from $35,5^{\circ} \%$ o to $36,7^{\circ} \%$

The width of shelf in Second Fishing Region is 35 to $40 \mathrm{Nm}$. The bottom of fishing grounds is mainly of sandy or sandmuddy type; only in coastal regions of Cap Barbas, Cap Blanc and Cap Timiris are appearing the stones and coral rocks (up to 30-120 m in depth).

Owing to an increased activity of trade wind the ,upwelling" is occuring at investigated shelf during the spring-summer season and the waters cold and rich in biogenic salts are brought-up from the depth of 300-400 m during such phenomenon.

\section{RESULTS}

Length .

The length analysis of gilt sardine was based on the measurements of 13434 fishes. During 1968, the largest fishes were caught in April and the smallest in September, while during 1969, the largest fishes were caught at the end of February, in July and September and the smallest in May. The length distribution of fishes caught in May was distinctly 
differing from the length distribution of fishes caught during the remaining months. This may be attributed to the fact that the sample from May was caught furthermost to North and East. According to the results obtained by Prosvirov (1960) the smallest and the least growing gilt sardines cumulate in the waters situated nearer to the coast, i.e. furthermost towards the East.

On Fig. 1 is presented the length distribution of gilt sardine caught in the particular years of the investigated period. It is seen that for 1968 the most numberously represented was the length class of $33 \mathrm{~cm}$, for 1969 - of $34 \mathrm{~cm}$, while for 1970 - dominated the gilt sardines of length $35 \mathrm{~cm}$. It is apparent from analysis of Fig.1 that during the subsequent years of examined period, the fishes caught were larger. This is particularly distinct in length distribution of fish caught in 1970 when about $85 \%$ were grouped within the five length classes: from 33 to $37 \mathrm{~cm}$.

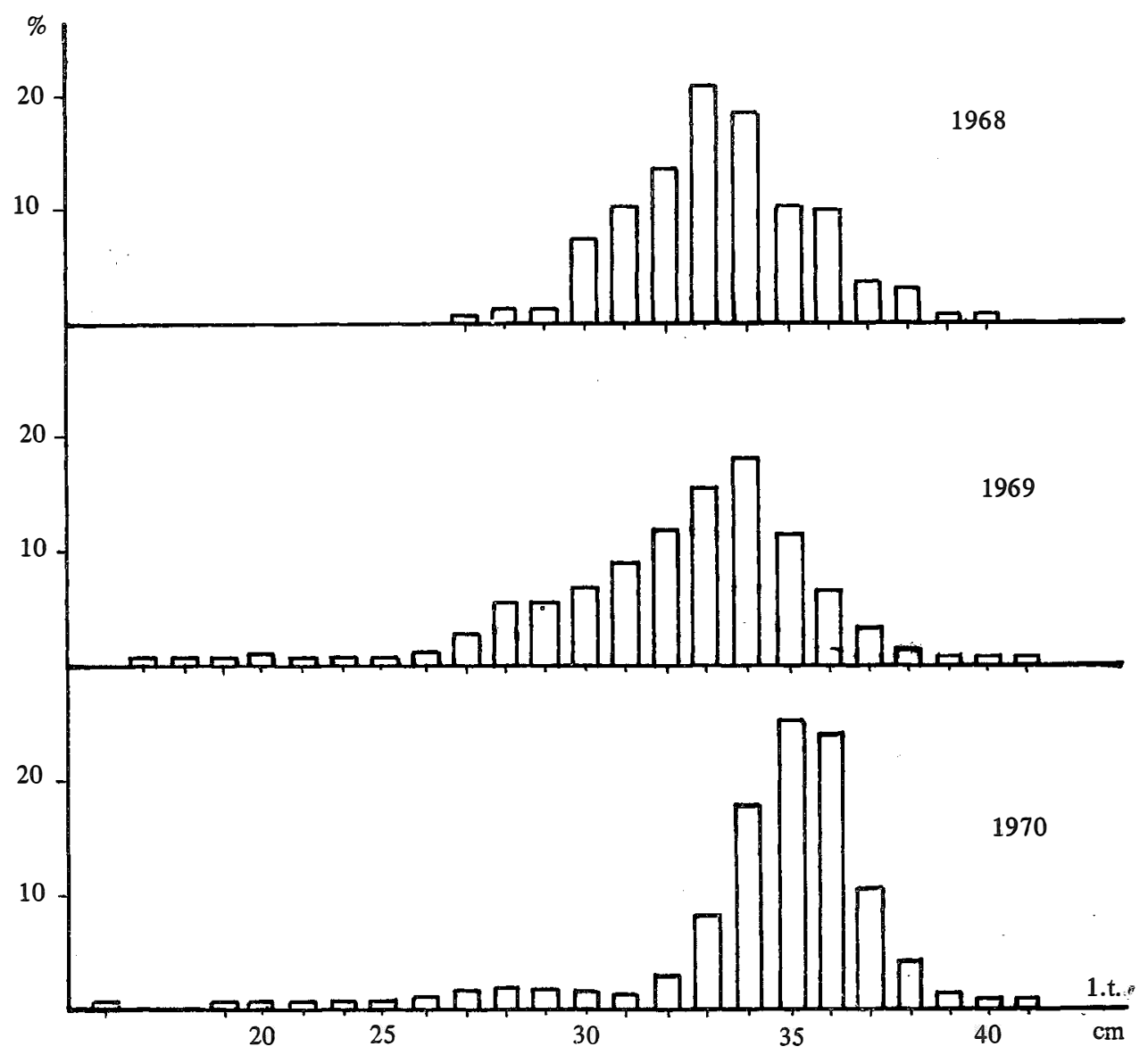

Fig. 1. Length distribution of gilt sardine for particular years 
Fig. 2 presents the length distribution for the whole material investigated with consideration of sex. It is seen that dominated the class $35 \mathrm{~cm}$ and the extent of length ranged between 18 and $41 \mathrm{~cm}$. In lower length classes (below $35 \mathrm{~cm}$ ) dominated generally the males while in class $35 \mathrm{~cm}$ and higher - the females. The range of length for males amounted to $21-40 \mathrm{~cm}$ and for females $-18-41 \mathrm{~cm}$.

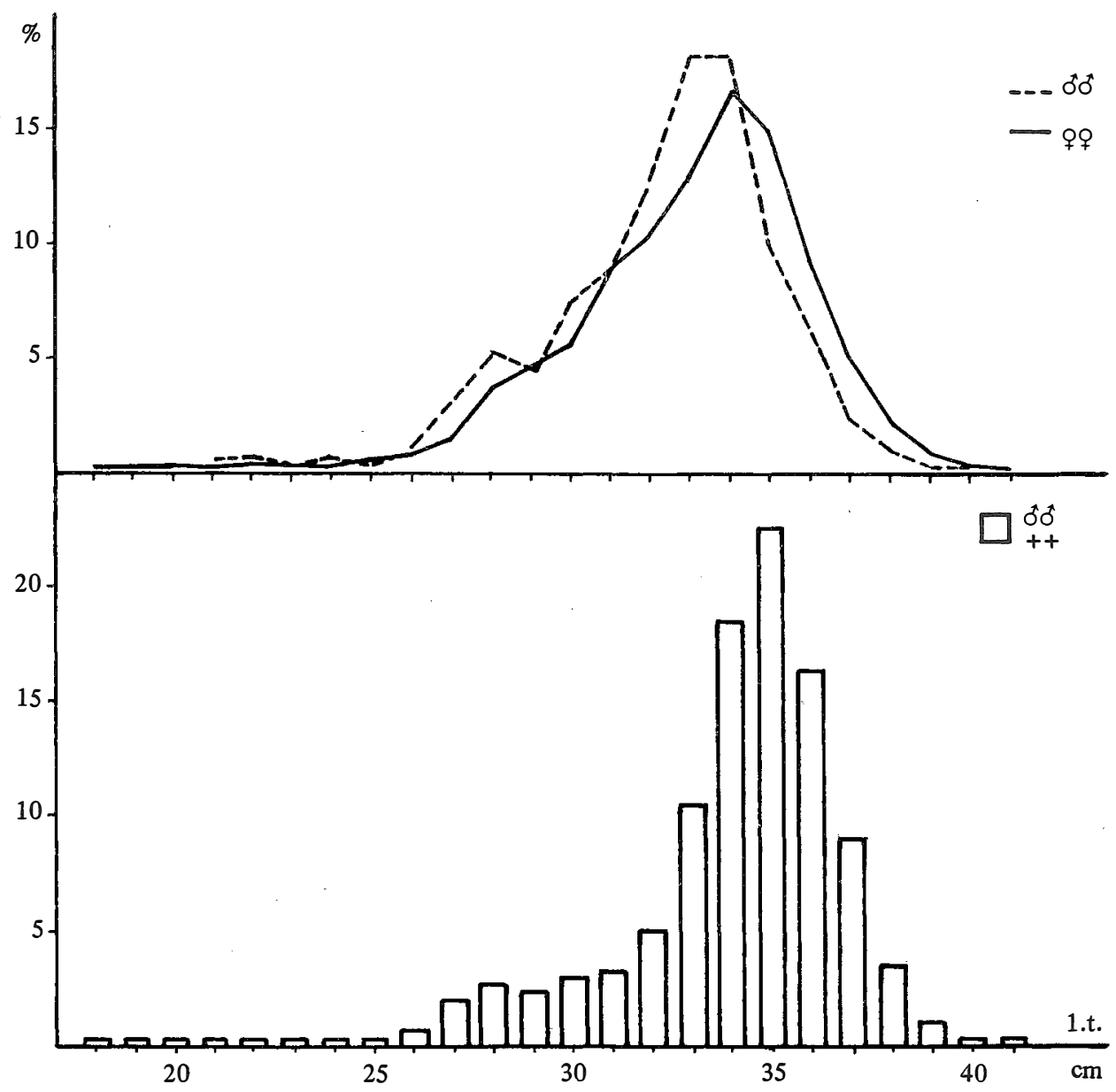

Fig. 2. Length distribution of gilt sardine for all material collected

Age

The age was determined according to the scales of 2836 gilt sardines; part of the results was verified against the otoliths and opercular bones. The results of age determination for the particular investigated years are presented on Fig.3. 


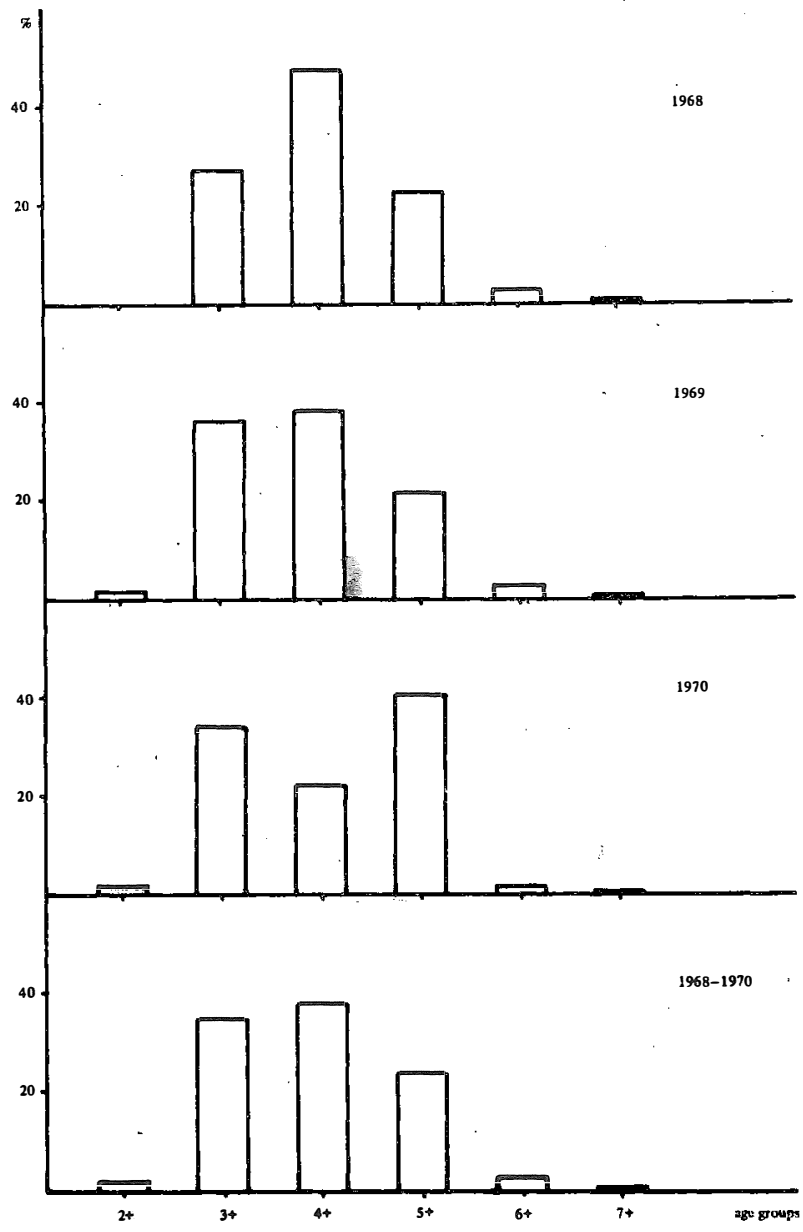

Fig. 3. Age composition of gilt sardine for particular years and all material

During 1968 distinctly dominated the 4-year specimen; in 1969 dominated also the 4-year specimen, while the quantity of 3-year specimen was only negligently lower. The participation of 5-year specimen was similiar to 1968 but dominating in 1970. For the whole material examined dominated the 4-year specimen with negligently lower participation of 3-year specimen and distinctly lower quantity of 5-year specimen. These 3 age-groups represented about $90 \%$ of the total examined fishes.

According to the changes of age composition for paricular investigated years, the gilt sardine of 1965, which formey the third age group in 1968, fourth in 1969 and fifth in 1970 , may be considered as relatively strong generation for the examined period, owing to its high participation in catches of the three subsequent years. Next generation were weaker, but the generation of 1967 seams to be near to the generation of 1965 . Such conclusions should, however, be taken with certain reserve owing to considerable short period of the investigation. 
Rate of growth

For correct determination of age and rate of growth, an estimation of period for annulus formation on scale is of considerable importance. Such estimation is difficult in case of gilt sardine, because it scales are very illegible and covered with additional false annulus.

As during 1969 the gilt sardines were fished nearly during all months, the percent of fish possessing the annulus on edge of scale was calculated in particular monthly samples. The highest percent of such scales were noted in August and slightly less in June and November.

On Fig. 4 are presented the average lengths attained by 3-6 years gilt sardines in subsequent months of 1969 , separately for each age group. Worth noting is the comparison of lengths, which the particular age groups are attaining at the beginning and end of a year, i.e. in January and November. Only the 3-year individuals are attaining larger length in November than in January (by $1 \mathrm{~mm}$ only). while the average length of the remaining age groups for November, is distinctly lower than for January. Such difference in length amounts to $9 \mathrm{~mm}$ for 4-year individuals, $10 \mathrm{~mm}$ for 5 -year and $15 \mathrm{~mm}$ for 6-year individuals.

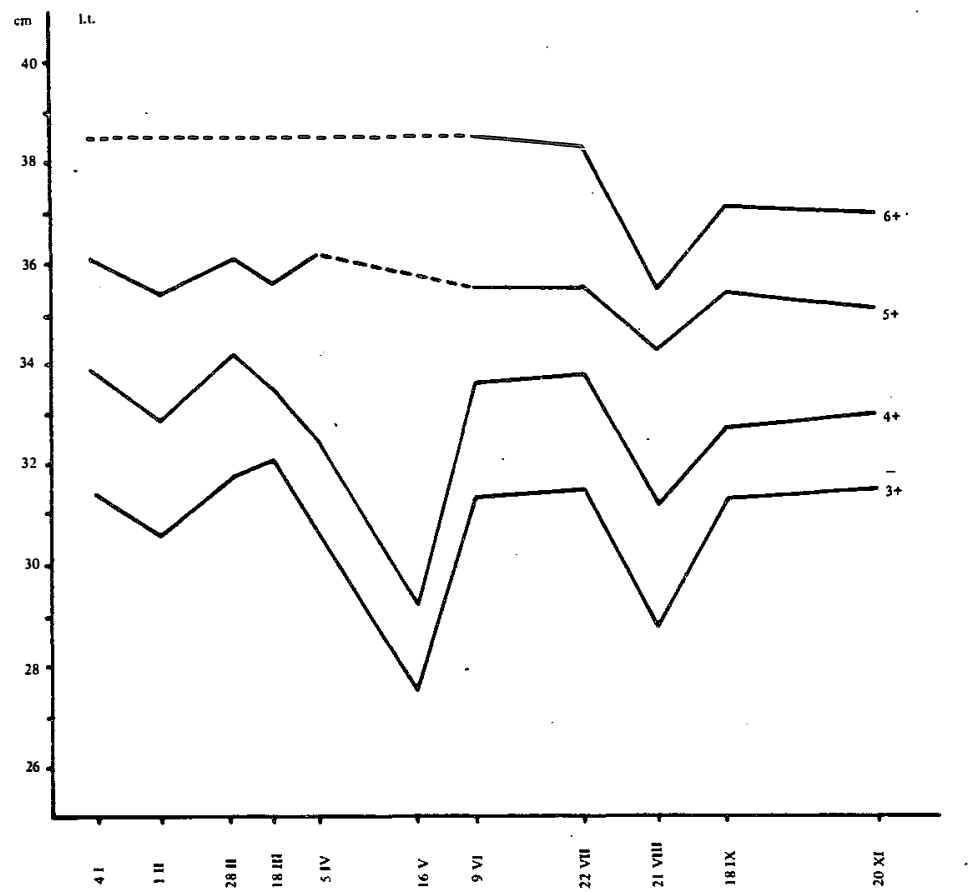

Fig. 4. Average length of various age-groups for particular months of 1969

Comparing the average length attained by age-groups during particular months, it is noted that the average lengths for subsequent months differ relatively negligently, with 
exception of those attained in May and August when rapid decrease of length is noted in comparison to April and July. If the sample of May shall be considered as not representing because comprises the smallest and the slowest in growth gilt sardines (specified under headline "Length") then the decrease of length in August may be explained as follows: assuming that in most cases the annulus is formed on scale during August (according to observation results of scales with annulus at the edge), it must be admitted that a fish examined during this month is calculated to one-year older age-group than a fish of July. Thus, the length of 4-year individual from August shall be close to the length of 3-year individual from July. In other words, the gilt sardines of particular age groups are transitting to one-year older age group during July-August. The observation results of the scales with annulus at edge are, thus, supported and the apparent decrease in length for January - November, within the particular age groups, is explained.

Basing on the above mentioned assumptions, it may be stated that, the period of annulus formation on scales of gilt sardine comprises the months from June to November and its peak prevails for August.

For determination of gilt sardine rate of length growth assumed in this work the back calculation method of Dahl-Lea; it was therefore necessary to check if between the growth of scale oral radius (on which the rate of growth was calculated) and the growth of gilt sardine length exists the direct proportion in compliance to the assumed method. For this purpose, the total length (longitudo totalis) and the size of oral radius scale were measured on 676 gilt sardines.

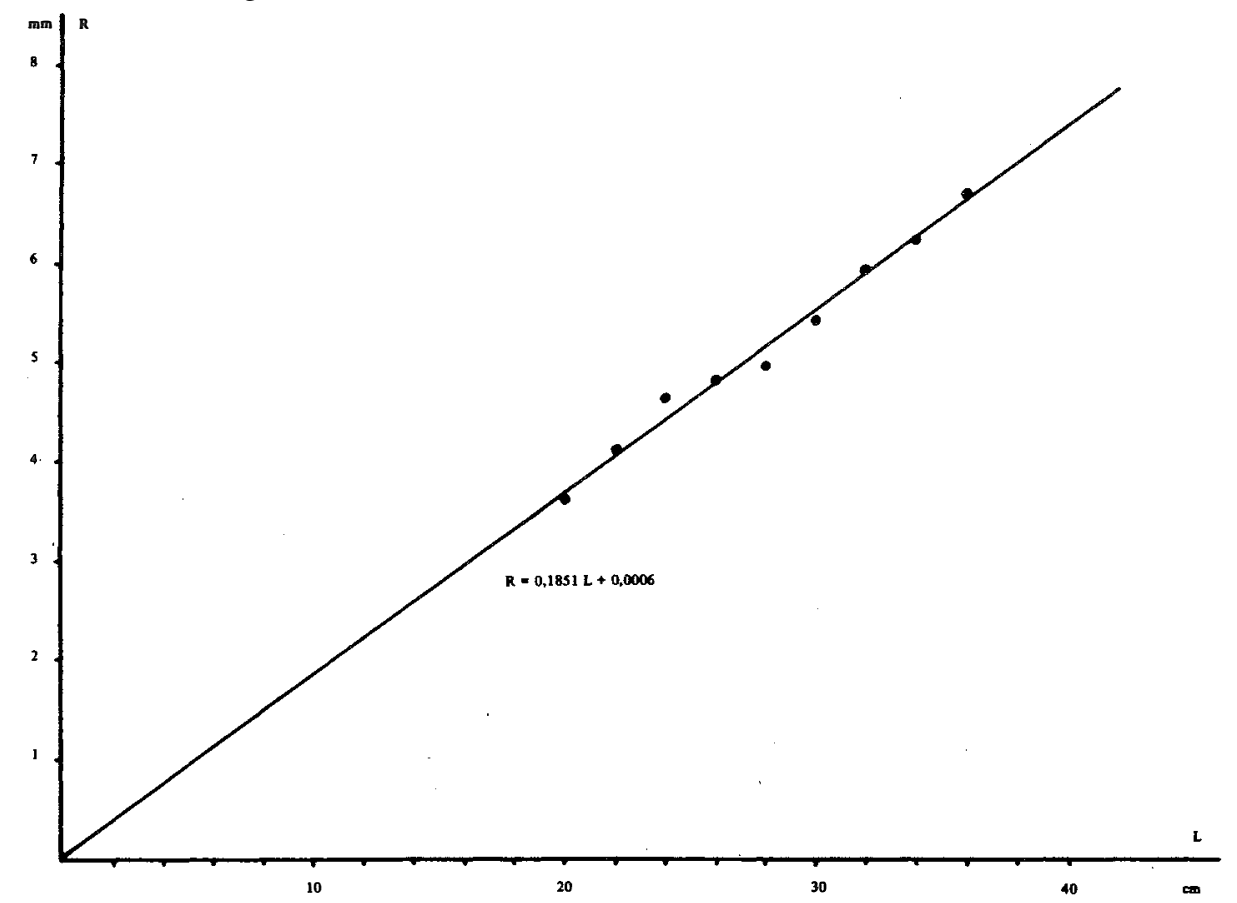

Fig. 5. Relationship of gilt sardine total length (L) to scale oral radius (R) 
The results of such measurements as the points corresponding to partial average, are presented on Fig.5; the coefficient of correlation was calculated and the equation for direct regression made according to formula of $\mathbb{R}$ omanowski (1952).

The calculated value of correlation coefficient $(r=0,996)$ proves that the oral radius of scale and the total length of gilt sardine are in strict linear interrelation and the straight obtained according to equation of regression $(R=0,1851 L+0,0006)$ is intersecting the axis $\mathbb{R}$ at minimal distance from the centre of coordinates arrangement. Therefore, the interrelation discussed may be assumed as directly proportional and the method of Dahl-Lea may be used for back calculations of gilt sardine growth without any correction.

The rate of length growth was based on the bach calculations of scales from 2458 fishes. On Fig. 6 presented the average rate of growth for the particular age groups. The slowest in growth were the 2-year and $7-y$ rear individuals and the quickest were the 3-year individuals. The differences in rate of growth for particular age groups are not exceedingly high and maximum difference for the second year of life between the length of 2- and 3-year individuals amounts to $3,9 \mathrm{~cm}$.

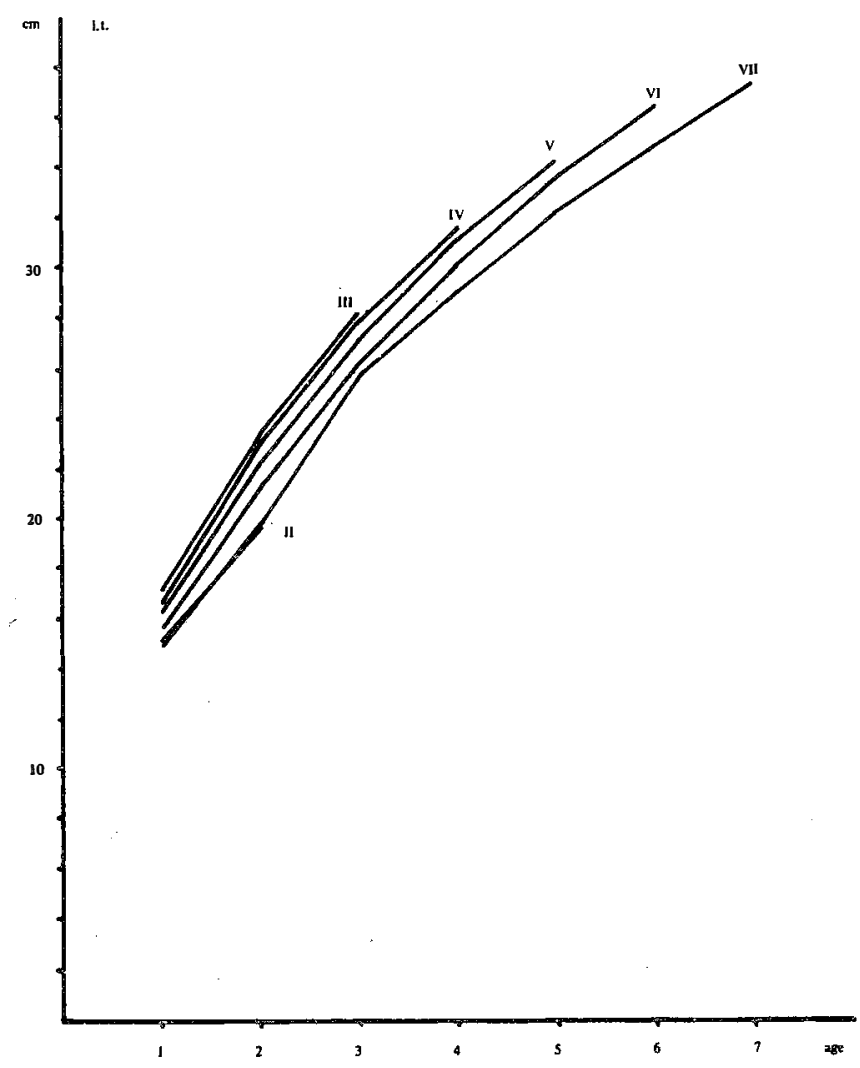

Fig. 6. Rate of length growth for particular age-groups 
Presented in Tab.2 are the average lengths of females and males for the subsequent years of life. The differences are very negligent and do not exceed $0,5 \mathrm{~cm}$.

Table 2

Length growth rate of gilt sardine males and females

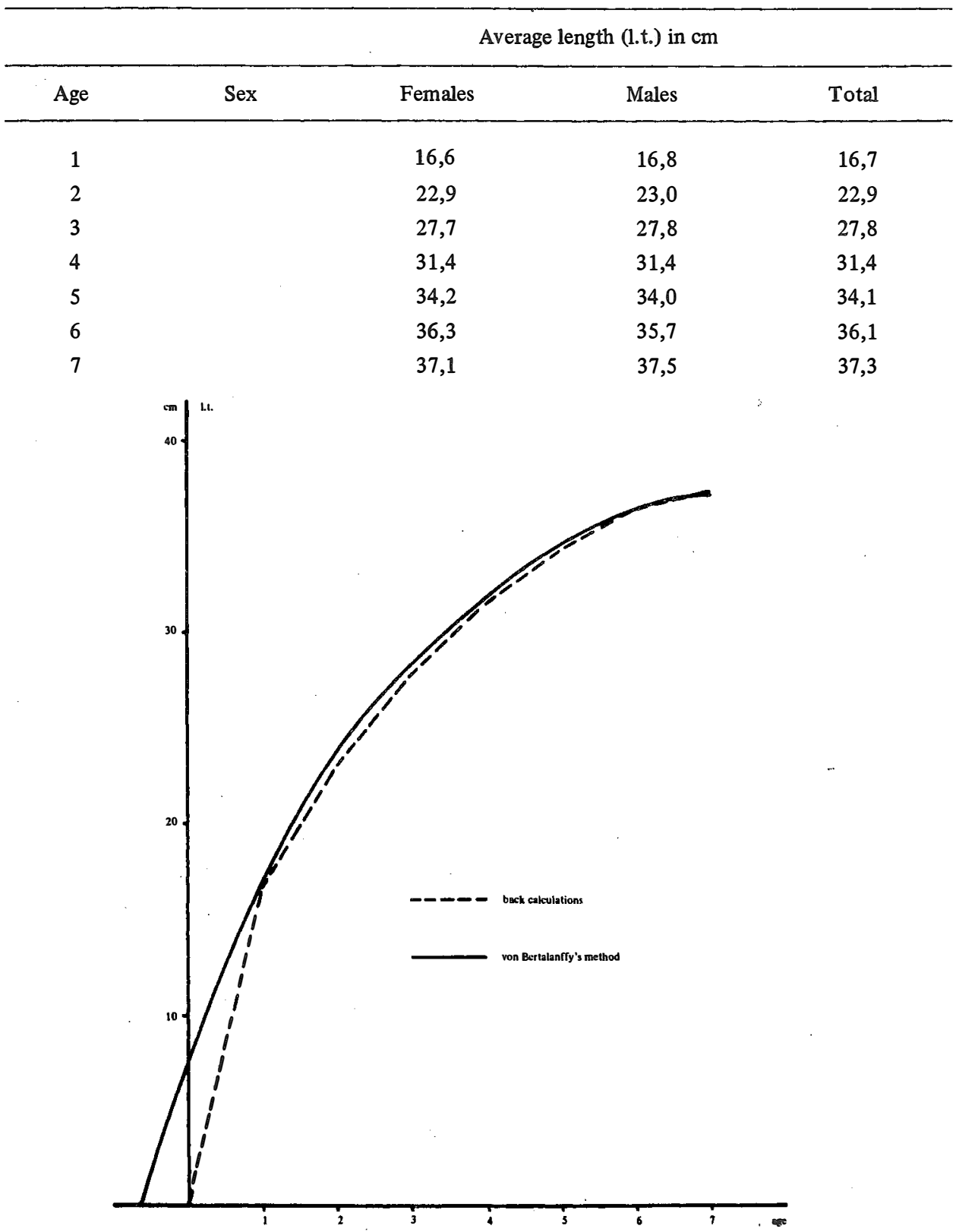

Fig. 7. Comparison of gilt sardine rate of growth calculated according to back reading method and equation of von Bertalanffy 
On Fig.7 presented the average rate of gilt sardine growth calculated by the method of back calculations and by equation of von Bertalanffy. It should be noted that the parameters of this equation were calculated without consideration of the length attained during the first year of life. Otherwise, the results obtained from equation of von Bertalanffy for the first years of life would considerably differ from the results obtained by the method of back calculations. The parameters of von Bertalanffy's equation obtained on the basis of the results of back calculation represent the following values:

$$
\begin{aligned}
& \mathrm{L}_{\infty}=40,7 \mathrm{~cm} \\
& \mathrm{t}_{\mathrm{o}}=-0,6283 \\
& \mathbb{K}=0,326
\end{aligned}
$$

Finally, the equation of von Bertalanffy calculated for gilt sardine assumes the following formula:

$$
1_{t}=40,7\left[1-e^{-0,326(t+0,6283)}\right]
$$

It may be ascertained from Fig.7 that, the results obtained from equation of von Bertalanffy are nearly covering with the results of back calculations. The growth of length is characteristic in relatively large increment during the first year of life and is decreasing successively during the following years.

In comparison of the present results with these of other authors (Postel, Rossignol after, Michonski (1964) who investigated the rate of growth of gilt sardine of Senegal and Congo region, it may be noted that the results differ negligently. However, the results of Navaro (after Michoniski (1964)) relating to sardine from Canary Islands and the results of El Maghraby, Botros and Soliman (1970) for the region of Mediterranean Sea prove that in these regions the rate of growth of gilt sardine is distinctly slower than for the North-West African shelf.

An interrelation between the length and weight of gilt sardine was determined according to generally accepted formula:

$$
\mathrm{W}=\mathrm{aL}^{\mathrm{n}}
$$

where:

$$
\begin{array}{ll}
\mathrm{W} & - \text { weight } \\
\mathrm{L} & \text { - length } \\
\text { a and } \mathrm{n} & - \text { coefficients. }
\end{array}
$$

The coefficients a and $n$ were calculated by the least square method based on the measurements of total length (1.t.) and body weight of 3089 gilt sardines with application of the formulas of Lagler (1959). The final form of interrelation between the length and weight ' of gilt sardine body is presented thus:

$$
W=0,01648 \mathrm{~L}^{2,8386}
$$

Graphically, the interrelation is presented on Fig.8.

The rate of weigth growth was calculated on the basis of the above discussed interrelation and is presented on Fig.9. It is seen that the curve for the rate of weight growth 
have "S" shape which is characteristic for majority of fish. This rate is slower during the first years of life, accellerates later on and decreases again towards the end of life.

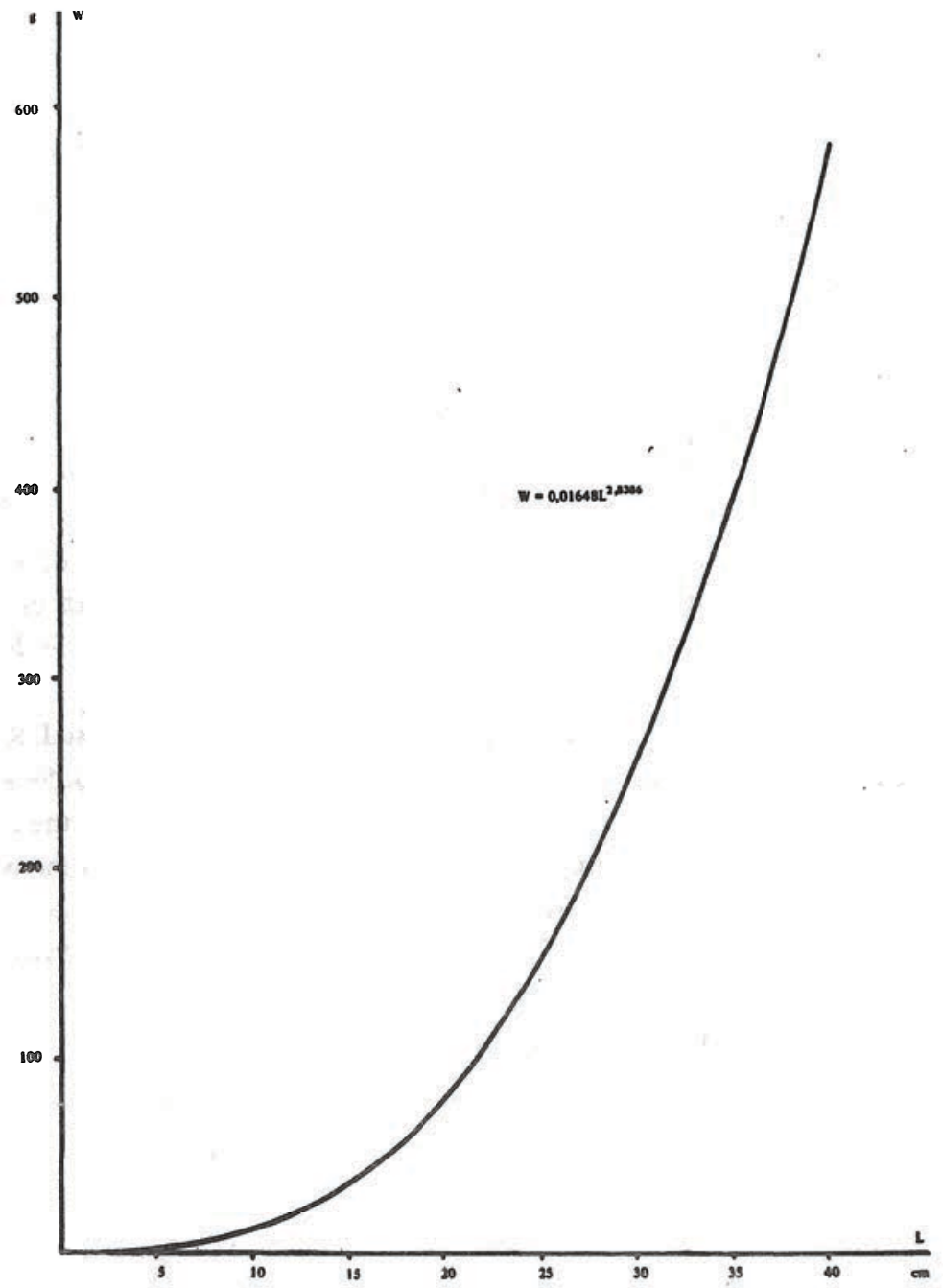

Fig. 8. Length - weight relationship

Maturity of gonads and fecundity

For determination of maturity stage of gonads used the scale of Maier and the coefficient of gonads maturity (weight of gonads expressed in percent of fish body weight). By Maier's scale, the stage of gonad maturity was determined for 3406 gilt sardines.

In the materials of 1968 , the gonads of examined fish were in I to IV stage of maturity acc. to Maier's scale. No spawning or spent fishes were noted. 
In June and July 1969 majority of examined fishes possessed already the matured gonads (V stage of Maier's scale) and the first spawning and spent individuals (VI and VII stage of gonad maturity) were observed in August. In September, the number of spawning and spent individuals was distinctly higher.

During 1970, the spawning gonads of gilt sardine males were observed already in May, while in June the spawning gonads possessed both the males and females.

Generally, basing on the analysis of material for the whole investigated period, it is ascertained that the spawning period of gilt sardine is widely distributed in time. The spawning fishes were noted during the period from May to November. Considering that during some years the matured fish (V stage of gonads maturity) appeared already in January, it is apparent that the period of sardine spawning is more spread in time than it could be assumed according to monthly samples within which the spawning fish was noted.

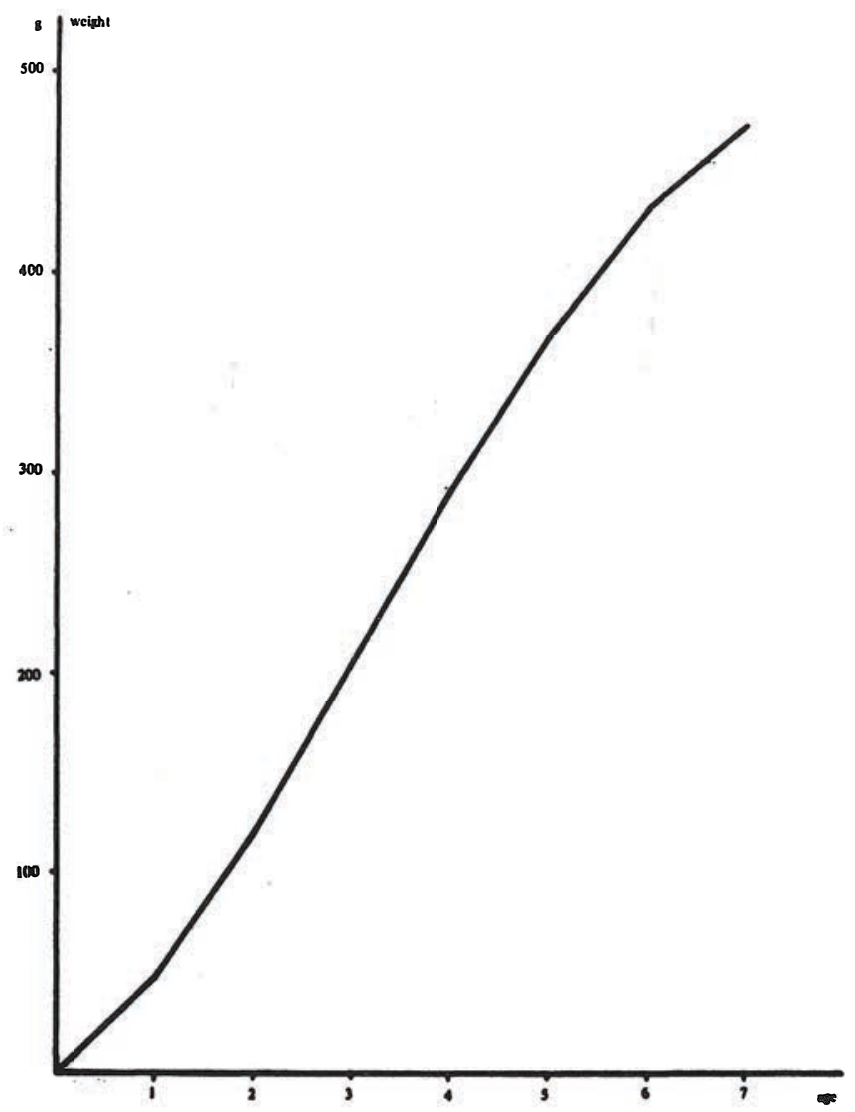

Fig. 9. Weight growth of gilt sardine

The coefficient of gonads maturity was calculated for 1933 fishes by the formula:

$$
q=\frac{g}{G} \cdot 100
$$


where:

q coefficient of gonads maturity,

$g$ weight of gonads,

$G$ - weight of fish.

To avoid an error which could be caused by various index of alimentary tract filling, the fish weight without entrails was used for the calculation of the above mentioned coefficient.

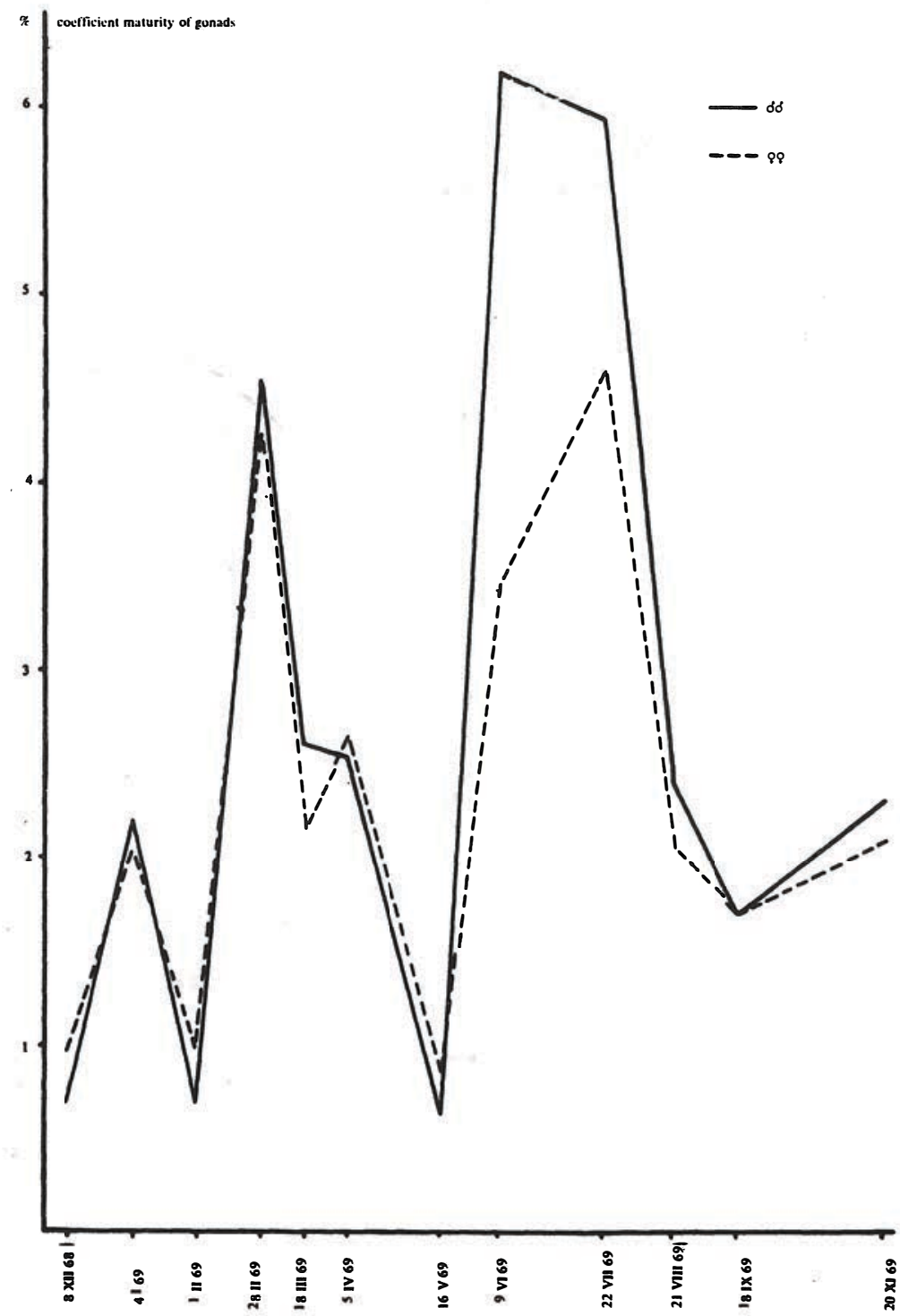

Fig. 10. Changes in coefficient of gonads maturity for particular months 
On Fig. 10 are presented, in form of the curve, the changes of coefficient value of gonads maturity for the period from December 1968 to November 1969. The coefficient attains the highest values towards the end of February in June and July and the lowest in December, at the beginning of February and in May.

The collected materials tend to indicate that the gilt sardine spawns probably twice in a year, i.e. towards the end of winter and during the summer-autumn season. The peak values of the coefficient of gonads maturity support such conclusion. The lack of spawning fishes in winter and spring samples could result due to fishing in this period beyond the spawning regions. The presence of matured fish in January also indirectly supports the conclusion on spring spawning of the gilt sardine.

The opinions of other authors on sardine spawning period are divided. Postel and Rossignol (after Biriukov (1960)) are of the opinion that the gilt sardines spawn once in a year. Probatov (1960), Boely, Champagnat and Conand (1969) give two periods of gilt sardine spawning, i.e. early spring and summer-autumn season.

The fecundity of gilt sardine was determined by weighing method of gonads of 45 females in IV and V maturity stage according to Maier's scale. In Tab. 3 presented the absolute fecundity calculated for the particular length classes. It may be seen that, in females accounted to the same length class, are noted very wide individual oscillations of absolute fecundity what generally is a typical phenomenon also for other species of fish.

Table 3

Absolute fecundity of gilt sardine in particular length-classes

\begin{tabular}{cccc}
\hline $\begin{array}{c}\text { Length-classes } \\
(\mathrm{cm})\end{array}$ & $\begin{array}{c}\text { Number } \\
\text { of specimen }\end{array}$ & $\begin{array}{c}\text { Average fecundity } \\
\text { (thous.) }\end{array}$ & $\begin{array}{c}\text { Individual } \\
\text { deviations }\end{array}$ \\
\hline $28-30$ & 3 & 49,6 & $28,6-62,1$ \\
$30-32$ & 1 & 69,2 & - \\
$32-34$ & 10 & 138,7 & $68,6-278,6$ \\
$34-36$ & 18 & 164,1 & $89,8-296,6$ \\
$36-38$ & 11 & 157,8 & $82,7-303,0$ \\
$38-40$ & 2 & 133,8 & $117,3-150,4$
\end{tabular}

Food and Feeding

The composition of gilt sardine food was determined according to analysis of alimentary tracts content of 64 gilt sardines caught in May and June 1970. As the food in majority of cases was strongly digested, no possibility existed for application of numerical or weighing method to calculate the participation of particular food components. Therefore, for the determination of gilt sardine food composition was used the method of frequency of occurence.

On Fig.11 presented the occurence frequency of particular food components. The most important are Cyclopoia, Euphausiacea, Calanoida and Harpacticoida, what proves 
that the crustacean plankton is the basic food of gilt sardine. The bottom organisms such as molluscs and echinoderms were appearing in lower quantities within the examined alimentary tracts.

Similar results on gilt sardine food obtained Semenova (1960). According to this author, the most frequently occuring food component of gilt sardine was Copepoda, while the benthos organisms were' appearing in negligent number of the examined fishes.

The intensity of gilt sardine feeding was determined by the alimentary tracts filling according to the assumed 5 -grade scale. The filling of stomachs was determined in 2781 gilt sardines and it shows distinct oscillation for the particular months. The smallest filling was noted for November, December and January and the highest for July.

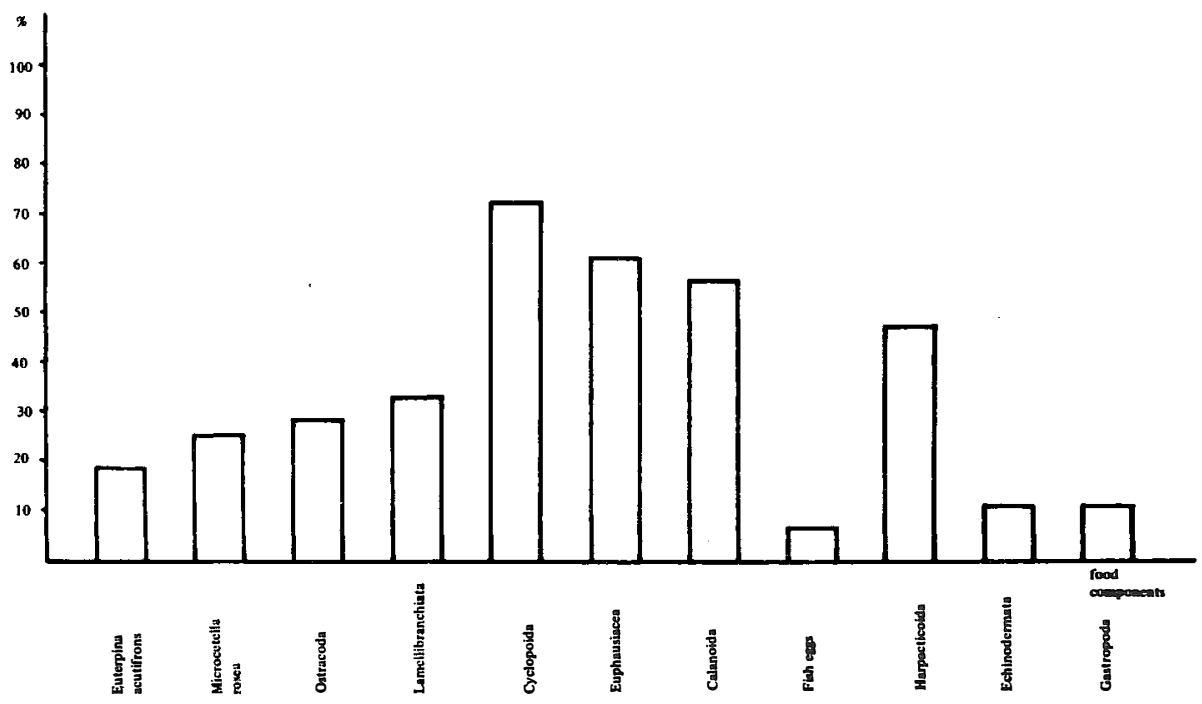

Fig. 11. Food composition of gilt sardine estimated by frequency of appearance

An estimation of alimentary tracts filling by the assumed scale is considerably subjective and the obtained results may possess certain error. Therefore, the index of filling was calculated for 346 gilt sardines caught between December 1968 and November 1969 , which is expressed by weight relation of food to fish. The average values of this index are presented in form of the curve on Fig. 12.

The lowest values of filling index prevail for November, December and January and the highest for May and July; thus, the results obtained are covering with the results of alimentary tracts filling estimated by means of the assumed scale. 


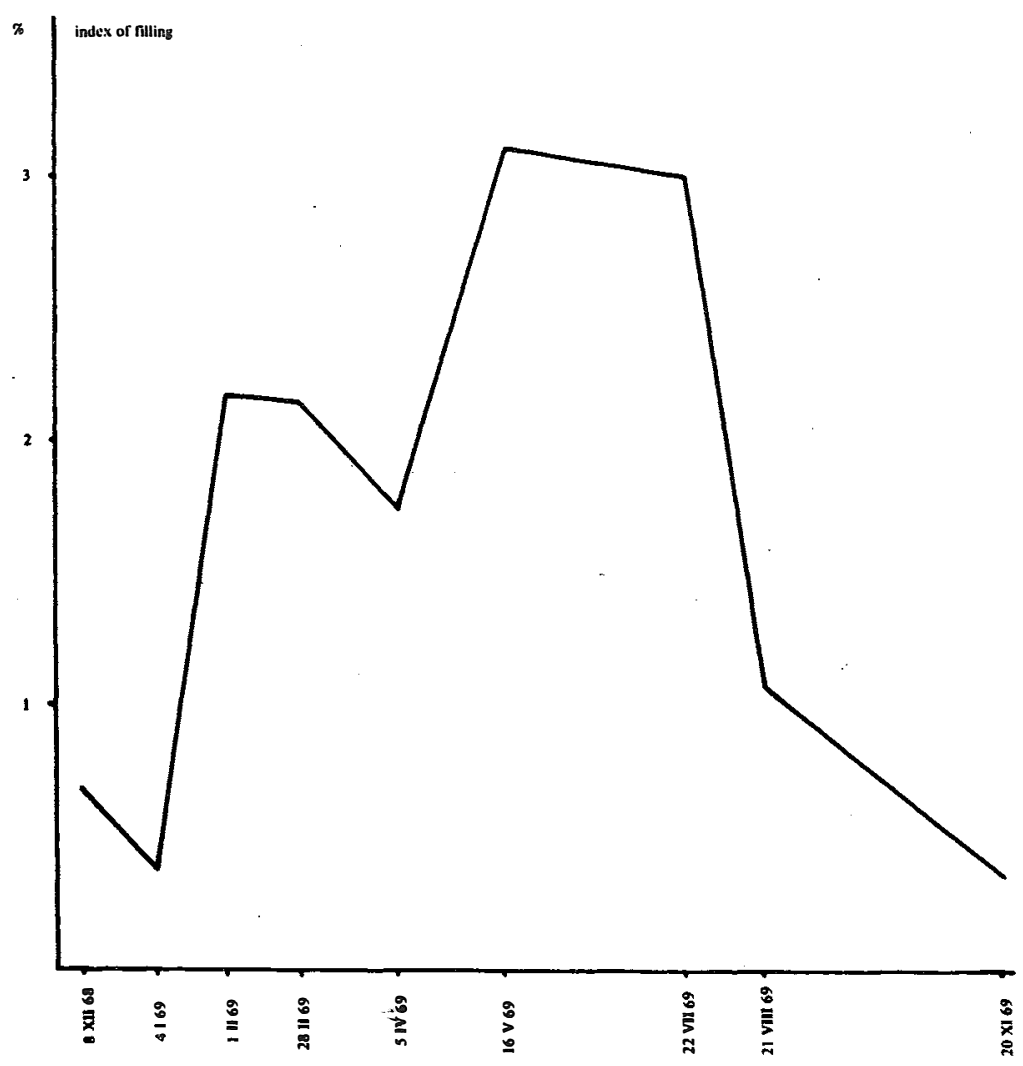

Fig. 12. Changes in index of filling for particular months

\section{CONCLUSIONS}

1. The length of examined gilt sardine oscillated from 18 to $41 \mathrm{~cm}$ and dominated the length class of $35 \mathrm{~cm}$. The age of gilt sardine was between 2 and 7 years; dominating was the age group of 4-year individuals with equally high participation of 3-and 5-year individuals.

2. The annulus starts forming on gilt sardine scale during the period June - November and its peak may be observed in August.

3. An interrelation between the oral radius of scale and total length (1.t.) of gilt sardine is very near to direct proportional and therefore, the method of Dahl-Lea for the back calculations of growth rate could be assumed without any corrections.

4. The rate of length growth was highest during the first year of life and was gradually decreasing during the subsequent years. The rate of weight growth is increasing until the 4th year of life, decreasing slowly during the next years and accellerates thenafter. 
5. The spawning period of gilt sardines prevails probably twice during a year, i.e. towards the end of winter and during the summer - autumn season.

6. The absolute fecundity for the examined fishes oscillated between ab. 29000 to ab. 303000 eggs. Noted wide individual differences within the same length classes.

7. The food of gilt sardine comprises mainly the crustacean plankton (Cyclopoida, Euphausiacea, Calanoida, Harpacticoida) The bottom organisms were encountered in relative negligent number of examined fishes.

8. The intensity of gilt sardine feeding is subject to distinct oscillation in annual cycle. The lowést was observed towards the end of autumn and at the beginning of winter (November, December, January) and the highest - during spring and summer (May and July).

\title{
REFERENCES
}

Birukov N.F., 1960: Rezultaty raboty tretej promyslovopoiskovej ekspedicji v ekvatorialnyje vody Atlanticeskogo Okeana. - Trudy BaltNIRO, wyp.5.

Boely T., Champagnat C., Conand F.,1969: Reproduction et cycle biologique de Sardinella aurita (C. et $\mathrm{V}$ ) des cotes senegalaises.

El Maghraby A.M., Botros G.A., Soliman I.A.M., 1970: Age and Growth Studies on Sardinella maderensis Lowe and Sardinella aurita Cuv. et Val. from the Mediterranean Sea at Alexsandria. - Bull. of the Inst. Of Ocean. and Fish., Alexsandria, 1.

Klimaj A., 1968: Łowiska i rybołówstwo szelfu Afryki Zachodniej. (Fishing and fishing grounds of W. African Shelf. - Guide to exercises). Przewodnik do ćwiczeń. Wyższa Szkoła Rolnicza, Szczecin.

Lagler K.F., 1959: Freshwater Fishery Biology. Dubuque - Jowa.

Michoński T., 1964: Sardyna atlantycka (Sardinella aurita), biologia, poĉowy i rozmieszczenie na Atlantyku Srodkowym. [Atlantic sardine (Sardinella aurita), its biology, fishing and distribution in Middle Atlantic]. Maszynopis (type-script), Instytut Ichtiologii, WSR Szczecin.

Probatov A.N., 1960' Vtoraja naucno-promyslovaja ekspedicja v vody sredniej Atlantiki (k zapadnoj Afrikie) s 31 I-VII 1958. na travlerach „Kazan” i „Alazeja”. - trudy BaltNIRO, vyp. 5.

Prosvirov E.S., 1960: Rezultaty rabot promyslowoj ekspedicji $1959 \mathrm{~g}$ v vodach sredniej Atlantiki.

Romanowski S., 1952: Podstawy statystyki matematycznej. (The basis of mathematical statistics). PWN Kraków.

Semenova G.W., 1960:Izucenije planktona i pitanija planktonojadnych ryb v vodach sredniej i ekvatorialnej Afriki. - Trudy BaltNIRO, vyp. 5.

Translated: Irena Kliche

\section{CHARAKTERYSTYKA BIOLOGICZNA SARDYNELI SARDINELLA AURITA CUV. ET VAL. 1847 Z ŁOWISK PÓŁNOCNO-ZACHODNIEJ AFRYKI}

\author{
Streszczenie
}

Niniejsze opracowanie ma na celu ustalenie podstawowych właściwości biologicznych sardyneli Sardinellaaurita Cuv. et Val. 1847. Ogółem zbadano 13434 ryby, złowione w okresie 1968-1970 na łowiskach szelfu Północno-Zachodniej Afryki.

Długość badanych sardyneli wynosiła od 18 do $41 \mathrm{~cm}$ (1.t.) a wiek - od 2 do 7 lat. Pierścień roczny zakłada się na łusce $w$ okresie czerwiec-listopad, a największe nasilenie tego procesu zaobserwowano w sierpniu. 
Ponieważ zależność pomiędzy długością całkowitą sardyneli a oralnym promieniem jej łuski jest bardzo zbliżona do zależności wprost proporcjonalnej, do wstecznych obliczeń tempa wzrostu długości zastosowano metodę Dahl-Lea. Tempo wzrostu długości jest najszybsze w pierwszym roku życia, a w następnych latach przyrosty długości zmniejszają się. Wzrost ciężaru, ustalony na podstawie zależności pomiędzy długością a ciężarem ciała, jest najszybszy w 3-cim i 4-tym roku życia, natomiast w latach poprzednich i następnych tempo wzrostu ciężaru jest wolniejsze.

Okres tarła sardyneli przypada prawdopodobnie 2 razy w roku: w końcu zimy i w okresie letniojesiennym. Zaobserwowano duże wahania indywidualne płodności absolutnej samic sardyneli w obrębie tych samych klas długości.

Głównym składnikiem pokarmu sardyneli jest plankton skorupiakowy (Cyclopoida, Euphausiacea, Calanoida, Harpacticoida). Organizmy denne spotykane były rzadziej i wniejszych ilościach. Najwyższą intensywność żerowania sardyneli stwierdzono w maju i lipcu, a najniższą - w listopadzie, grudniu i styczniu.

БИОЛОГИЧЕСКАЯ ХАРАКТЕРИСТИКА САРДИНЕЛЛЫ SАRDINЕLLA AURITA CUV.ЕT VAI 1847 РАЙОНОВ ЛОВА СЕВЕРО-ЗАПАДНОЙ АФРИКИ

\section{$\mathrm{P}$ e $\mathrm{z} 10 \mathrm{Me}$}

Настоящая работа имеет своей целью установить основные биологические особенности сардинеллы Sardinella aurita Cuv et Val.1847. В общей сложности исследовали 13.434 экз. рыбы, выловленной в период с 1968 по 1970 Г. в районах лова шельфа Северо-Западной Африки。

Длина исследуемых экземпляров сардинеллы составляла от 18 до $41 \mathrm{~cm}$ (l.t॰), а возрасть - от 2 до 7 лет. Годичное кольцо образуется на чешуе в июне-ноябре, а наиболыпая интенсификация этого процесса отмечалась в августе месяце.

Так как зависимость между общей длиной сардинеллы и оральным радиусом её чешуи очень близка к пямо пропорциональной, для обратных вычислений темпа роста длины применили метод Дааль-Лея. Темп роста длины более высокий в первом году жизни, а в последующи годы прирост длины уменьшается. Увеличение веса, определённое на основе зависимости между длиной и весом тела протекает быстрее в 3 и 4 годах жизни, а в предыдущие годы, а такще и в последующие, темп роста веса является более медленным.

Нерест сардинеллы происходит, вероятно, два раза в год: в конце зимы и в летне-осенний период. Отмечены большие индивидуальные колебания абсолютной плодовитости самок сардинеллы в границах одних и тех же размеров их тела.

Основным компонентом корма сардинеллы является ракообразный планктон (Cyclopoida, Euphausiacea, Calanoida, Harpacticoida).

Донные организмы встречались реже и в меньшем количестве. Самая высокая интенсивность натула сардинеллы отмечена в мае и в июле, а самая низжая - в ноябре, декабре и январе.

Adress:

Received 3 VIII 1972

Dr Jerzy Szypuła

Insty tut Ichtiologii AR

Szczecin, ul, Kazimierza Królewicza 4

Polska-Poland 